Mini-Review Open Access

\title{
Resistance to Viruses of Potato and their Vectors
}

\author{
Peter Palukaitis* \\ Department of Horticultural Sciences, Seoul Women's University, Seoul 139-774, Korea \\ (Received on June 3, 2012; Accepted on July 1, 2012)
}

\begin{abstract}
Potato (Solanum tuberosum) is one of the most important food crops worldwide and yields of potato can be affected by virus infection. While more than $\mathbf{4 0}$ viruses have been found in potato, only nine viruses (potato leafroll virus, potato viruses $A, M, S, V, X$ and $Y$, potato moptop virus and tobacco rattle virus) and one viroid (potato spindle tuber viroid) have a significant economic impact on potato, worldwide. This review describes the geographical distribution of the most important viruses infecting potato and the genes for resistance or tolerance that have been identified against these various infectious agents. In some cases such resistance genes have been found only in other Solanum species. Few genes for resistance to the vectors of these viruses have been obtained and even fewer have been deployed successfully. However, transgenic resistance in potato has been achieved against seven of these disease agents.
\end{abstract}

Keywords : potato, potato viruses, resistance, vectors

Potato (Solanum tuberosum ssp. tuberosum) is the world's fourth major food crop. The modern potato is a selfcompatible outbreeding tetraploid plant derived from introductions to Europe from South America in 1570. These introductions were of the cultivated ancestral potato Andigena (S. tuberosum ssp. andigena), another tetraploid, which probably evolved from diploid species. Potato had been adapted to long-day growth conditions by the end of the 18th century, by selection for early tuber-bearing plants giving high yields. With time, a progressive "degeneration" of the crop was observed, increasing with subsequent generations. This was recognized in the early 20th century as being due to virus infection (Salaman, 1921). Subsequently, it was realized that several viruses were transmitted by aphids to potato, and then later still that other vectors transmitted several viruses to potato. These various observations led to the introduction of virus disease regulations, the development of seed certification schemes and breeding for virus resistance in a number of countries. Thus, high-grade,

\footnotetext{
*Corresponding author.

Phone) +82-2-970-5614, FAX) +82-2-970-5610

E-mail) peterp@swu.ac.kr
}

virus-free seed tubers could be produced in areas that were isolated climatically and geographically from both sources of infection and reduced numbers of virus vectors. However, the various sanitary measures are labor-intensive, expensive and difficult to maintain and thus breeding for resistance may be a preferred option, in the long term. This mini-review describes the major, agronomically-important potato viruses, as well as resistance genes to both these viruses and their vectors, which have been identified and deployed.

\section{Potato Viruses}

About 40 viruses and two viroids can infect potato naturally. Another 22 viruses and four viroids can infect potato experimentally. However, of those viruses that infect potato naturally, only nine viruses and one viroid are considered to have a significant economic impact on a worldwide basis (Table 1). The other viruses either are not known to have an impact or have effects limited to specific locations. Of the other 13 viruses, several currently are limited in their distribution to certain areas of Asia, or the Americas and generally are not found in potato, unless alternate hosts for their vectors (thrips, leafhoppers and whiteflies) are absent due to drought or other environmental factors. Thus, it is conceivable that many of these viruses may yet emerge into viruses problematic in potato.

The economic effects of virus infection vary with location, potato cultivars and other environmental factors. Viruses such as Potato leafroll virus (PLRV) and Potato virus $Y$ (PVY) can affect yield substantially, with up to $80 \%$ losses, while viruses producing mild or latent symptoms, such as Potato virus $X(\mathrm{PVX})$ and Potato virus $S$ (PVS), show yield losses of at most 10 to 20\% (Burton, 1989; Kojima and Lapierre, 1988).

PLRV is probably the most important and damaging potato virus on a worldwide basis and is found in all regions where potato is grown. PVY is also widespread and causes considerable damage, depending on the cultivar of potato and the strain of virus. PVY is more common than PLRV in some regions of the world. The other potyviruses of potato, Potato virus $A$ (PVA) and Potato virus V (PVV), are often 
Table 1. The main viruses of potato

\begin{tabular}{|c|c|c|c|}
\hline Virus species (abbreviation) & Genus & Transmission & Global distribution \\
\hline Potato leaf roll virus (PLRV) & Polerovirus & Aphid - persistent & Worldwide \\
\hline Potato virus Y( PVY) & Potyvirus & Aphid - non-persistent & Worldwide \\
\hline Potato virus A (PVA) & Potyvirus & Aphid - non-persistent & Worldwide \\
\hline Potato virus V(PVV) & Potyvirus & Aphid - non-persistent & Peru, France, The Netherlands, UK \\
\hline Potato virus $X(\mathrm{PVX})$ & Potexvirus & Contact & Worldwide \\
\hline Potato mop-top virus (PMTV) & Pomovirus & Spongospora subterranea & $\begin{array}{c}\text { Andes, North America, China, Japan, } \\
\text { Russia, Northern Europe }\end{array}$ \\
\hline Tobacco rattle virus (TRV) & Tobravirus & Trichodorid nematodes & $\begin{array}{l}\text { Europe, China, Japan, New Zealand, } \\
\text { North/Central/South America }\end{array}$ \\
\hline Potato virus $S$ (PVS) & Carlavirus & Contact (aphid - non-persistent) & Worldwide \\
\hline Potato virus $M(\mathrm{PVM})$ & Carlavirus & Aphid - non-persistent (contact) & Worldwide \\
\hline Potato spindle-tuber viroid (PSTVd) & Pospiviroid & Contact (aphid) & Worldwide \\
\hline
\end{tabular}

grouped together with PVY (as "mosaics") in virus disease regulation schemes, since they are not found as frequently and usually are not associated with severe disease; PVA can be found worldwide (except in the Andes) and causes symptoms varying from mild to severe, while PVV has a very limited distribution and until recently was not considered important. PVX occurs worldwide, but generally produces only mild symptoms. Nevertheless, PVX could still cause reductions in tuber yield. In particular, PVX is a problem in mixed infections with potyviruses, where a severe synergistic disease is produced. The other four viruses, Potato virus M(PVM), PVS, Potato mop-top virus (PMTV) and Tobacco rattle virus (TRV) are important, but only in localized areas, even though some (PVS and PVM) have a worldwide distribution (Table 1). PMTV is found primarily in cooler climates, while TRV is found in light sandy soils, which favor its nematode vectors. The only significant viroid in potato, Potato spindle tuber viroid (PSTVd), occurs in various locations, including N. and S. America, China and Eastern Europe, but it is not considered indigenous to potato in Western Europe (Table 1).

All of the above viruses and the viroid are transmitted through tubers, while only PSTVd is transmitted through true seeds. In addition, PVX, PVS, PVM and PSTVd are transmitted by contact, TRV is transmitted by Trichodorid nematodes, PMTV is transmitted by the protist Spongospora subterranea, and PLRV, PVY, PVA, PVV, PVM and some isolates of PVS are transmitted by aphids (Table 1). In some cases, PSTVd can be transmitted by aphids via co-encapsidation in virions of PLRV (Querci et al., 1997).

\section{Resistance to potato viruses}

Barker and Dale (2006) defined six types of resistance to various potato viruses. These included resistance to infection (previously known as field resistance), resistance to virus accumulation, resistance to virus movement, mature plant resistance, tolerance, and resistance to virus vectors. Resistance to infection is a reduction in the number of plants that become infected under field conditions. In resistance to virus accumulation, the plants become infected but virus accumulates only to low levels in the plants. In resistance to virus movement, the virus is impeded in its movement to other parts of the plant, including the tubers. Mature plant resistance occurs in most cultivars against most viruses, but varies with timing, environmental conditions and virus strain. Tolerance is a resistance to disease, in which virus accumulates, but the crop shows little or no effect. Most of the specific resistance genes described in potato specify resistance to viruses in which infection is limited by inducing either an extreme resistance (ER) with little or no virus accumulation at the site of infection and no movement, or a hypersensitive response (HR), in which a necrotic lesion developed following infection, usually limiting virus infection to the area around the site of inoculation (Solomon-Blackburn and Barker, 2001a, b). Genes specifying an ER or an HR, listed in Table 2, have been identified for resistance against PVY, PVA, PVV, PVX, PVS and PVM. These have been incorporated in potato lines to limited extents (see below).

\section{PLRV}

Breeding for resistance to PLRV has been limited by a scarcity of sources of complete resistance and by the laborintensive field screening procedures required to assess the resistance. Sources of resistance to PLRV have been identified, but few cultivars exhibit strong resistance. Only one resistant cultivar, Pentland Crown, is grown widely in the UK. The resistance in Pentland Crown incorporated both resistance to infection and resistance to virus accumulation. The partial resistance to virus infection is polygenic (Davidson, 
Table 2. Host genes for resistance in potato

\begin{tabular}{|c|c|c|c|c|}
\hline Virus & Resistance Type & Gene (synonym) & Source & Reference \\
\hline \multicolumn{5}{|l|}{ Potyviruses } \\
\hline $\mathrm{PVY} / \mathrm{PVA} / \mathrm{PVV}$ & ER & $R y_{\text {sto }}\left(=R^{l}=R y\right)$ & S. stoloniferum & {$[1-3]$} \\
\hline PVY & $\mathrm{ER}(\mathrm{Y})$ & $R y_{\text {sto }}^{\text {na }}\left(=R^{2}\right)$ & S. stoloniferum & {$[1,3,4]$} \\
\hline PVA & $\operatorname{HR}(\mathrm{A})$ & & & \\
\hline PVV & $\mathrm{ER}(\mathrm{V}) / \mathrm{HR}(\mathrm{V})$ & & & \\
\hline PVY/PVA & $\mathrm{ER}(\mathrm{Y}) / \mathrm{HR}(\mathrm{A})$ & $R y_{\text {sto }}^{r n a}\left(=R^{3}\right)$ & S. stoloniferum & {$[1]$} \\
\hline PVY & HR & $R y_{\text {sto }}{ }^{n l}\left(R y n=N y_{\text {sto }}{ }^{l}\right)$ & & {$[1,2]$} \\
\hline PVY & HR & $R y_{\text {sto }}{ }^{2}\left(R^{5}=N y_{\text {sto }}{ }^{2}\right)$ & S. stoloniferum & [1] \\
\hline PVA & ER & $N a_{s t o}\left(R^{6}=R y m\right)$ & S. stoloniferum & {$[1,2]$} \\
\hline PVA & ER & $R a\left(=R a_{s t o}\right)$ & S. stoloniferum & [5] \\
\hline PVA & ER/HR & $R a_{a d g}$ & S. tuberosum spp. andigena & [6] \\
\hline PVY & ER & $R y_{a d g}$ & S.t. spp. andigena & {$[7,8]$} \\
\hline $\mathrm{PVY}^{\circ}$ & HR & $N y_{a d g}$ & S.t. spp. andigena & [8] \\
\hline $\mathrm{PVY} / \mathrm{PVA}$ & HR & $N y_{d m s}\left(=N^{y}\right)$ & S. demissum & {$[1,9]$} \\
\hline PVA & $\mathrm{HR}$ & $R y_{d m s}{ }^{a}\left(N a_{d m s}=N^{a}\right)$ & S. demissum & {$[1,9]$} \\
\hline PVY/PVA & ER & $R y_{\text {hou }}$ & S. hougasii & [1] \\
\hline PVY/PVA & $\mathrm{HR}$ & $N y_{\text {chc }}$ & S. chacoense & {$[1]$} \\
\hline PVY & HR & $N y\left(=N y_{t b r}\right)$ & S. tuberosum & {$[4,10,11]$} \\
\hline PVY & HR & $N y-1$ & S.t. spp. Tuberosum & [12] \\
\hline $\mathrm{PVA} / \mathrm{PVY} \mathrm{Y}^{\circ}$ & HR & $N a_{t b r}(=N a)$ & S. tuberosum & {$[1,13]$} \\
\hline PVA strain A & HR & $N a_{K E}\left(=N a_{K E t b r}\right)$ & S. tuberosum & {$[14]$} \\
\hline PVY strain C & HR & $N c_{t b r}(=N c)$ & S. tuberosum & {$[1,15]$} \\
\hline PVY strain C & HR & $N c_{s p l}$ & S.sparsipilum & {$[16]$} \\
\hline PVV & HR & $N v\left(=N v_{t b r}\right)$ & S. tuberosum & {$[4,17]$} \\
\hline \multicolumn{5}{|l|}{ PVX } \\
\hline $\operatorname{PVX}(1,2,3,4)^{\mathrm{a}}$ & ER & $R x_{a d g}$ & S.t. spp. andigena & {$[1,18]$} \\
\hline $\operatorname{PVX}(1,2,3,4)$ & ER & $R x\left(=R x_{t u b}=R x_{t b r}\right)$ & S.t. spp. tuberosum & {$[1,19-21]$} \\
\hline $\operatorname{PVX}(1,2,3,4)$ & ER & $R x_{a c l}$ & S. acaule & {$[1,22]$} \\
\hline $\operatorname{PVX}(1,2,3,4)$ & ER & $X^{I}$ & S. acaule & {$[1,9]$} \\
\hline \multirow[t]{2}{*}{$\operatorname{PVX}(1,2,3,4)$} & HR & $R x_{a c l}^{n}\left(X^{n}=N x_{a c l}\right)$ & S. acaule & {$[1,9]$} \\
\hline & & & S.t. spp. andigena & [23] \\
\hline $\operatorname{PVX}(1,2,3,4)$ & HR & $N x_{c h c}$ & S. chacoense & [1] \\
\hline $\operatorname{PVX}(1,3)$ & $\mathrm{HR}$ & $\mathrm{Nx}_{\mathrm{tbr}}{ }^{\mathrm{spl}}$ & S. sparsipilum & {$[1]$} \\
\hline $\operatorname{PVX}(1,3)$ & HR & $N x_{t b r}(=N x)$ & S. tuberosum & {$[1,13]$} \\
\hline PVX (2) & HR & $N b_{t b r}(=N b)$ & S. tuberosum & {$[1,15]$} \\
\hline PVX & HR & $N x_{p h u}$ & S. phureja & {$[24,25]$} \\
\hline $\operatorname{PVX}(\mathrm{HB})^{\mathrm{a}}$ & ER & $R x_{H B}\left(=R x_{H B s c r}\right)$ & S. sucrense & [26] \\
\hline $\operatorname{PVX}(2)$ & ER & $R x_{c}\left(=R x_{C P_{s c r}}\right)$ & S. sucrense & {$[26]$} \\
\hline \multicolumn{5}{|l|}{ PVS } \\
\hline PVS & ER & $s S_{t b r}(=s)$ & S. tuberosum & {$[27]$} \\
\hline PVS & HR & $N s$ & S.t. spp. andigena & {$[18,28,29]$} \\
\hline \multicolumn{5}{|l|}{ PVM } \\
\hline PVM & HR & $\mathrm{Nm}$ & S. megistracrolobum & {$[18,30,31]$} \\
\hline PVM & & $G m$ & S. gourlayi & {$[29,31]$} \\
\hline \multicolumn{5}{|l|}{ PLRV } \\
\hline PLRV & & $R l r_{e t b}$ & S. etuberosum & {$[32,33]$} \\
\hline
\end{tabular}

${ }^{\text {a }}$ PVX strain groups $1,2,3,4$ and $\mathrm{HB}$.

1 = Cockerham, 1970; 2 = Ross, 1961; 3 = Barker, 1997; 4 = Jones, 1990; 5 = Barker, 1996; 6 = Hämäläinen et al., 1998; $7=$ Munoz et al., 1975 ; $8=$ Valkonen et al., 1994; $9=$ Cockerham, 1958; $10=$ Hutton, 1951; $11=$ Davidson, 1980; $12=$ Szajko et al., 2008; $13=$ Cadman, $1942 ; 14=$ Valkonen et al., 1995a; $15=$ Cockerham, 1943; $16=$ Moury et al., 2011; $17=$ Fribourg and Nakashima, 1984; $18=$ Cockerham, $1955 ; 19=$ Ross, 1986; 20 = Fernandez-Northcote, $1990 ; 21=$ Mills, $1965 ; 22=$ Ross, $1954 ; 23=$ Swiezynski, $1994 ; 24=$ Tommiska et al., $1998 ; 25=$ Valkonen et al., 1995b; 26 = Brown et al., 1984; 27 = Bagnall and Young, 1972; $28=$ Baerecke, 1967; $29=$ Was and Dziewonska, 1984; $30=$ Swiezynski et al., 1993; 31 = Dziewonska and Ostrowska, 1978; 32 = Novey et al., 2007; and 33 = Kelley et al., 2009. 
1973), while a single dominant gene controls resistance to virus accumulation (Barker, 1987; Barker and Solomon, 1990; Brown and Thomas, 1994; Solomon-Blackburn et al., 2003/2004). Resistance to virus accumulation has been described from a range of $S$. tuberosum breeding lines and other related material (Barker and Harrison, 1985; Chavez et al., 1988; Franco-Lara and Barker, 1999; Gase et al., 1988; Swiezynski et al., 1988; Wilson and Jones, 1993; Van den Heuvel et al., 1993). The most resistant tetraploid genotypes had between 1 and 5\% of the PLRV levels found in susceptible clones. A number of useful sources of resistance have been detected in wild Solanum germplasm, including $S$. brevidens, $S$. etuberosum, $S$ chacoense and $S$. phureja (see Solomon-Blackburn and Barker, 2001a); however, none of these have been deployed in commercial cultivars. Resistance controlled by a single gene from $S$. etuberosum, designated $R l r_{e t b}$, and mapped to chromosome IV, has been crossed into a potato cultivar and resulted in a decrease in virus levels (Kelly et al., 2009; Novy et al., 2007). Resistance to infection by PLRV in some German potato cultivars was derived by introgression of genes from $S$. demissum (Davidson, 1980; Ross, 1966). Resistance controlled by a single gene conferring an HR was identified, but has not been used widely, since the plants developed systemic necrosis under high inoculum pressure. Immunity to infection by PLRV has been identified in $S$. chacoense, although this is inherited polygenically. One major and two minor quantitative trait loci (QTL) accounted for 50 to $60 \%$ of the resistance to PLRV (Marczewski et al., 2001). The major QTL was mapped to chromosome XI, while the two minor ones were mapped to chromosomes V and VI. Therefore, potato cultivars resistance to PLRV can be developed, especially with the aid of marker-assisted selection.

\section{Potyviruses}

There are many cultivars of potato that contain HR genes conferring a useful level of resistance to potyviruses. Some genes are specific to strains of PVY or PVA, while others show resistance to a broad range of strains of PVY, PVA and PVV. These various sources of resistance were derived in earlier breeding programs, by selecting cultivars that withstood virus degeneration better than others within the potato gene pool.

Several major strains of PVY occur: $\mathrm{PVY}{ }^{\mathrm{O}}$, or the common strain, which is severe in potato, and $\mathrm{PVY}^{\mathrm{N}}$ ("necrotic" strain), which is mild in potato (but is severe and induces systemic necrosis in tobacco). While previously rare in most countries, $\mathrm{PVY}^{\mathrm{N}}$ and a recombinant between $\mathrm{PVY}^{\mathrm{O}}$ and $\mathrm{PVY}^{\mathrm{N}}$ designated $\mathrm{PVY} \mathrm{NTN}^{\mathrm{NTN}}$, which causes potato tuber necrotic ringspot disease (severe necrosis) in the tubers of some cultivars, have spread into a number of European countries, as well as into North America. Two genes, $R y_{\text {sto }}$ and $\mathrm{Ry}_{a d g}$, providing resistance to $\mathrm{PVY}^{\mathrm{O}}$ have been shown to be effective against all strains of PVY; $R y_{\text {sto }}$ also provides resistance to PVA and PVV. These genes were derived from S. stoloniferum and S. tuberosum ssp andigena, respectively; $\mathrm{Ry}_{\text {adg }}$ mapped to a distal region of potato chromosome XI (Hämäläinen et al., 1997), while $R y_{\text {sto }}$ mapped towards the end of chromosome XII (Flis et al., 2005; Song et al., 2005; Valkonen et al., 2008). Both resistance genes control an ER to virus infection. $S$. tuberosum ssp andigena also was a source of a dominant HR gene for resistance to PVA $\left(R a_{a d g}\right)$, as well as a source of a recessive resistance $(r a)$ to systemic movement of PVA; both of these genes were linked to Ry $\mathrm{ydg}_{\mathrm{g}}$ on chromosome XI (Hämäläinen et al., 2000). Genes encoding an HR to PVY in potato $\left(N y_{t b r}\right)$ and in $S$. sparsipilum $\left(N c_{s p l}\right)$ were found to be either allelic or map very close on chromosome IV (Moury et al., 2011).

Relatively few cultivars have ER to these potyviruses, despite attempts being made to introgress ER to them since the 1940s. This is probably because such ER genes were generally introduced more recently to the $S$. tuberosum gene pool, and they were introduced from relatively few sources. Moreover, S. stoloniferum (the source of genes $R y_{\text {sto }}$ and $R y_{\text {stona }}$ ) does not intercross freely with $S$. tuberosum and hybrids are often male sterile. No potato cultivars produced in the UK are known to have a $R y$ gene, although several potato cultivars containing the $R y$ gene have been produced in Germany, Hungary, The Netherlands and Poland, undoubtedly due a higher priority for PVY resistant cultivars in those countries.

\section{PVX}

There are many potato cultivars that contain single dominant genes for resistance to PVX including the HR genes $N c_{t b r}$, $N x_{t b r}$ and $N b_{t b r} N x_{p h u}$, as well as the ER genes $R x_{t b r}, R x_{a d g}$ or $R x_{a c l}$. Many of the HR genes were introduced unknowingly during breeding programs incorporating wild species from South America, since the mid-18th century. Although the gene $N x_{t b r}$ for resistance to PVX (Cadman, 1942; Cockerham, 1970) has been used widely for decades, it still confers very useful resistance, albeit it does not provide resistance to all PVX strains. Resistance-breaking strains have been found (Jones, 1982, 1985), but they have not become prevalent, as there is a fitness cost associated with resistance-breaking. The dominant $N x_{p h u}$ gene, derived from $S$. phureja and conferring an HR against PVX, has been mapped to the long arm of potato chromosome IX (Tommiska et al., 1998). The dominant gene $N b_{t b r}$, which confers an HR against PVX isolates from strain groups 1 and 2, has been mapped to the upper arm of potato chromosome V (Marano et al., 2002). Introgression of the ER genes to PVX has occurred in 
several countries since the early 1950s. Potato cultivars with $R x_{t b r}, R x_{a d g}$ or $R x_{a c l}$ have been produced in the USA, Germany, Argentina, UK and Ireland (Ross, 1986). Two $R x$ genes, $R x 1$ and $R \times 2$, originating from $S$. tuberosum ssp andigena and $S$. acaule, respectively, and encoding a comprehensive ER to PVX, have been isolated and cloned (Bendahmane et al., 1999, 2000). $R x 1$ mapped to potato chromosome XII, while Rx2 mapped to chromosome V. The $R x l$ gene has been expressed as a transgene in two Nicotiana species and potato, where it has been shown to induce ER to PVX (Bendahmane et al., 1999). The transgenic $R x$-mediated resistance was indistinguishable from the $R x$-mediated phenotype in potato cultivar Cara. Both $R x$ genes have a similar organization to a number of other plant resistance genes functional against other types of pathogens (Jones and Jones, 1997). These contain various conserved elements, such as nucleotide binding sites and leucine-rich repeats (Bendahmane et al., 1999, 2000). However, unlike resistance genes that are specific to bacteria, fungi, or insects, resistance genes specific to plant viruses do not encode membrane-anchoring domains. Thus, these virus resistance gene products interact with the viral elicitors (or other host proteins that previously have reacted to the viral elicitors) once these are present inside the cell.

\section{Carlaviruses}

PVS and PVM are commonly found in potato, but are essentially symptomless in most of the widely grown potato cultivars. Much less effort has been devoted to breeding for resistance to PVS and PVM than to PLRV, PVX or the potyviruses, partly because PVS and PVM cause less damage than most other viruses, and partly because there has been less work identifying sources of resistance to PVS and PVM. A major dominant gene $(\mathrm{Nm})$ for hypersensitivity to PVM was identified in S. megistracrolobum (Ross, 1986), while a major dominant gene $(\mathrm{Gm})$ conferring resistance to infection by PVM from S. gourlayi was reported (Dziewonska and Ostrowska, 1978). A few sources of resistance to PVS have been described, including resistance to infection, identified in potato cultivars Adretta and Saco produced in Germany and the USA, respectively (Ross, 1986). A localized hypersensitivity to PVS is conferred by the dominant gene $N s$, originally introgressed from $S$. tuberosum ssp. andigena. A few potato cultivars have been produced containing the Ns gene, including the cultivars Szignal and Fantasia, generated in Hungary and Germany, respectively (Ross, 1986).

\section{TRV}

There are several potato cultivars immune to TRV infection, including Record, Hermes and Lady Rosetta. There also are several potato cultivars in which resistance mediated by an HR-like response occurs, including Pentland Dell and Russet Burbank. The HR-like response to TRV is different from that described against with PVX or potyviruses, where the HR can provide a useful level of resistance. After infection by TRV, the HR does not occur in leaves, but in tubers, where it is undesirable because of the detrimental effect of the necrotic arcs, referred to as corky ringspot (or spraing), on tuber flesh quality, although the HR-type response can provide a certain measure of resistance to further infection in the plant. Resistance in potato cultivar Record appears to be conferred by a single resistance gene with linked AFLP markers identified (M.F.B. Dale, personal communication). The HR-like response in Pentland Dell appears to be due to a major heritable factor. The resistance in Record vs. Pentland Dell is due to two different major genes involved in the processes of resistance and the development of corky ringspot symptoms in different populations. The identification of usable markers associated with these resistance genes will enhance greatly the breeding for improved resistance to TRV, which currently relies on field assessments that are slow, labor-intensive and at often unreliable, depending upon environmental conditions.

\section{PMTV}

Resistance to PMTV has not been introgressed deliberately in breeding programs and there is no reliable method to screen for tolerance or resistance to infection in the field (Solomon and Wastie, 1988). Some cultivars of potato show tolerance to PMTV, but others show various levels of disease. For example, potato cultivar Saturna, widely grown in Scandinavia, is very sensitive (Nielsen and Mølgaard, 1997; Sandgren, 1995), while cultivars Appell and Desirée are more resistant to infection by PMTV. Moreover, there are differences in susceptibility among cultivars, with cultivars Bintje, King Edward, Maris Peer, and Record being more tolerant and producing symptomless infected tubers (Arli-Sokmen et al., 1998; Kurppa, 1990).

\section{PSTVd}

There are no reports of resistance in commercial potato cultivars to PSTVd and few reports of natural resistance to PSTVd. The Commonwealth Potato Collection (CPC) (www.hutton.ac.uk/commonwealth-potato-collection) lists $S$. acaule, $S$. guerreroens and $S$. berthaultii as showing some resistance. Further effort put into screening accessions of these species would likely show other sources of resistance. PSTVd represents a particular problem to potato breeders, since it is transmitted through true seed. Thus, breeders must prevent PSTVd from becoming established 
in the breeding parents. This can be done by rigorous screening prior to use of such materials and removing any local sources of infection, as there is a measurable frequency of PSTVd being transmitted by aphids if encapsidated into PLRV particles in co-infected plants (Querci et al., 1997). Resistance to PLRV would also be desirable in those regions where PSTVd is endemic to prevent aphid-transmitted PSTVd from becoming a problem.

\section{Resistance to virus vectors}

Resistance to aphid vectors has been sought in Solanum species. Such a breeding trait should be useful as it could help to reduce virus spread. A type of resistance to aphids has been found in the wild Bolivian potato species Solanum berthaultii. The resistance is based on differences in two types of glandular hairs. When the A-type hairs are ruptured, the aphids are entrapped within their contents. By contrast, the B-type hairs entangle aphids. This causes the aphids to struggle and thus rupture more A-type hairs (Tingey and Laubengayer, 1981). Moreover, the B-type hairs contain (E)- $\beta$-farnescene, the main component of the alarm pheromone for most aphids, and thus this chemical acts to repel aphids (Gibson and Pickett, 1983). In a field trial, accessions of $S$. berthaultii with type A and B hairs or only with type A were infected equally by PVY; however, the spread of PLRV was reduced significantly by the B type hairs (Rizvi and Raman, 1983). Unfortunately, it has been found to be difficult to incorporate the genes specifying the B-type hairs without also introducing undesirable characteristics such as later maturing plants, fewer tubers and lower yields (Kalazich and Plaisted, 1991). In addition, resistance to aphids based on reduced feeding or colonization has been observed (Mottaghinia et al., 2011; Pompon et al., 2010; Salas et al., 2010), but this may not be sufficient to prevent infection by potyviruses.

Resistance to powdery scab, caused by $S$. subterranea, has been found in Solanum species and certain potato cultivars. PMTV is transmitted by motile zoospores of $S$. subterranea; however, it is not known whether resistance to powdery scab could be developed to a level that would provide resistance to natural infection by PMTV.

\section{Transgenic resistance}

Individual resistance to most of the major potato viruses has been generated in tobacco by transgenic expression of viral sequences derived from various viral genes including those encoding the capsid protein, the replicase, movement protein and proteinases (reviewed by Dasgupta et al., 2003; Kawchuk and Prüfer, 1999; Lomonossoff, 1995; Palukaitis and Zaitlin, 1997; Prins et al., 2008). However, there are fewer examples where such sequences of potato virus genomes have been incorporated into the potato genome and have been shown to confer resistance to those viruses. Nevertheless, this has been accomplished with sequences derived from PLRV (Barker et al., 1992; Brown et al., 1995; Ehrenfeld et al., 2004; Graham et al., 1997; Kawchuk et al., 1997; Kawchuk et al., 1990; Murray et al., 2002; Palucha et al., 1998; Rovere et al., 2001; Thomas et al., 2000), PVY (Chi et al., 2005; Hefferon et al., 1997; MakiValkama et al., 2001; Malnøe et al., 1994; Missiou et al., 2004; Okamoto et al., 1996; Racman et al., 2001; Schubert et al., 2004; Smith et al., 1995; Sokolova et al., 1994; Wefels et al., 1993), PVA (Nie et al., 2008), both PLRV and PVY (Arif et al., 2009), PVX (Doreste et al., 2002; Hoekema et al., 1989; Spillane et al., 1998; Xu et al., 1995), both PVX and PVY (Lawson et al., 1990), PMTV (Germundson et al., 2002; Melander et al., 2001), TRV (Melander, 2006) and PSTVd (Matousek et al., 1994; Yang et al., 1997). Solomon-Blackburn and Barker (2001a) have suggested that transgenic resistance derived by stacking sequences from several viruses may offer to best means of obtaining multiple virus resistance, given that the sources of host-derived resistance to the various potato viruses involve different breeding lines and even different Solanum species. Stacking of genes to create resistance to multiple viruses has been conferred against three cucurbit viruses [cucumber mosaic virus (CMV), watermelon mosaic virus 2 and zucchini yellow mosaic virus in transgenic cantaloupe (Cucumis melo L. var cantalupensis naudin; Fuchs et al., 1997) and squash (Cucurbita pepo L.; Fuchs et al., 1998)], against three viruses (TMV, PVY and CMV) in transgenic tobacco (Zhu et al., 2008), against four tospoviruses in transgenic Nicotiana benthamiana (Bucher et al., 2006) and against either three (PVY, PVA, and PLRV) or five (PVY, PVA, PLRV, TRV and PMTV) potato viruses in tobacco (Chung and Palukaitis, 2011). However, only recently has such stacked resistance been reported against multiple viruses (PVX, PVY and PLRV) in potato (Arif et al., 2012). It will be interesting to see whether further resistance to multiple viruses can be produced, and for how many viruses such resistance can be conferred.

An alternative to using viral sequences to confer resistance is the use of modified translation factors such as eIF4E. This has proven successful in tomato transgenically-expressing a naturally mutated $e I F 4 E$ gene, which showed resistance two strains of PVY and pepper mottle virus, but not to tobacco etch virus (Piron et al., 2010), and in potato transgenically-expressing a modified $S$. tuberosum eIF4E gene, mutated to contain changes present in the Capsicum annuum $p v r 1^{2}$ gene, conferring resistance to PVY in capsicum (Cavatorta et al., 2011), which also showed resistance to PVY. 


\section{Conclusions}

Sources of natural resistance have been identified against most of the nine principal viruses infecting potato. In some cases such resistance genes have been found only in other, Solanum species that are often non-tuber-bearing. In many cases, these resistance genes either have not been introgressed into potato, or have only been introgressed sparingly. This may be due to polygenic nature of the resistance, the particular virus target being largely symptomless in the cultivars in use, or some sterility or incompatibility associated with use of the resistant parent. Few genes for resistance to the vectors of these viruses have been obtained and even fewer have been deployed successfully. Transgenic resistance using virally-derived sequences has been demonstrated against seven of the nine viruses and against PSTVd, all in potato; however, these have not been deployed due to resistance of consumers to genetically-modified food crops. The use of natural or artificially-modified virus resistance genes introduced into genetically modified plants offers an alternative possibility for conferring resistance against viruses. In addition, the determination of genome sequences of potato (Potato Genome Sequencing Consortium, 2011) and tomato (Tomato Genome Consortium, 2012) should facilitate the isolation of further resistance genes against these viruses, which can then be introduced into potato by cisgenic technology (Schouten et al., 2006). It will be interesting to see how rapidly resistance to multiple viruses can be achieved by either cisgenic or transgenic approaches, whether such resistance genes also function against viruses transmitted by the natural vectors of those viruses, and how durable such resistance will be in the field.

\section{Acknowledgments}

The author thanks Finlay Dale and Hugh Barker for discussions and unpublished information. This study was supported by a special grant from Seoul Women's University in 2011.

\section{References}

Arif, M., Azhar, U., Arshad, M., Zafar, Y., Mansoor, S. and Asad, S. 2012. Engineering broad-spectrum resistance against RNA viruses in potato. Transgenic Res. 21:303-311.

Arif, M., Thomas, P. E., Crosslin, J. M. and Brown, C. R. 2009. Development of molecular resistance in potato against potato leaf roll virus and potato virus Y through Agrobacteriummediated double transgenesis. Pak. J. Bot. 41:945-954.

Arli-Sokmen, M., Barker, H. and Torrance, L. 1998. Factors affecting the detection of potato mop-top virus in potato tubers and improvement of test procedures for more reliable assays.
Ann. Appl. Biol. 133:55-63.

Baerecke, M.-L. 1967. Überempflindlichkeit gegen das S-Virus in der Kartoffel in einem bolivanischen Andigena-Klon. Züchter 37:282-286.

Bagnall, R. H. and Young, D. A. 1972. Resistance to virus $\mathrm{S}$ in the potato. Am. Potato J. 49:196-201.

Barker, H. 1987. Multiple components of the resistance of potatoes to potato leafroll virus. Ann. Appl. Biol. 111:641-648.

Barker, H. 1996. Inheritance of resistance to potato viruses $\mathrm{Y}$ and A in progeny obtained from potato cultivars containing gene Ry: evidence for a new gene for extreme resistance to PVA. Theor. Appl. Genet. 93:710-716.

Barker, H. 1997. Extreme resistance to potato virus V in clones of Solanum tuberosum that are also resistant to potato viruses $\mathrm{Y}$ and A: evidence for a locus conferring broad-spectrum resistance. Theor. Appl. Genet. 95:1258-1262.

Barker, H. and Dale, M. F. B. 2006. Resistance to viruses in potato. In: Natural Resistance Mechanisms of Plants to Viruses, ed. by G. Loebenstein and J.P. Carr, pp. 341-366, Springer, Dordrecht, The Netherlands.

Barker, H. and Harrison, B. D. 1985. Restricted multiplication of potato leafroll virus in resistant potato genotypes. Ann. Appl. Biol. 107:205-212.

Barker, H. and Solomon, R. M. 1990. Evidence of simple genetic control in potato of ability to restrict potato leaf roll virus concentration in leaves. Theor. Appl. Genet. 80:188-192.

Barker, H., Reavy, B., Kumar, A., Webster, K. D. and Mayo, M. A. 1992. Restricted virus multiplication in potatoes transformed with the coat protein gene of potato leafroll luteovirus - similarities with a type of host gene-mediated resistance. Ann. Appl. Biol. 120:55-64.

Bendahmane, A., Kanyuka, K. and Baulcombe, D. C. 1999. The $R x$ gene from potato controls separate virus resistance and cell death responses. Plant Cell 11:781-791.

Bendahmane, A., Querci, M., Kanyuka, K. and Baulcombe, D. C. 2000. Agrobacterium transient expression system as a tool for the isolation of disease resistance genes: application to the $R x 2$ locus in potato. Plant J. 21:73-81.

Brown, C. R. and Thomas, P. E. 1994. Resistance to potato leafroll virus derived from Solanum chacoense: Characterization and inheritance. Euphytica 74:51-57.

Brown, C. R., Fernandez-Northcote, E. N., Jayasinghe, U. and Salazar, L. 1984. Breeding virus-resistant potato cultivars for developing countries. CIP Circular 1:1-4.

Brown, C. R., Smith, O. P., Damsteegt, V. D., Yang, C. P., Fox, L. and Thomas, P. 1995. Suppression of PLRV titer in transgenic Russet-Burbank and Ranger-Russet. Am. Potato J. 72:589597.

Bucher, E., Lohuis, D., van Poppel, P. M. J. A., Geerts-Dimitriadou, C., Goldbach, R. and Prins, M. 2006. Multiple virus resistance at high frequency using a single transgene construct. $J$. Gen. Virol. 87:3597-3701.

Burton, W. G. 1989. The Potato - 3rd Edition. Longman, Harlow, UK.

Cadman, C. H. 1942. Autotetraploid inheritance in the potato: some new evidence. J. Genet. 44:33-52. 
Cavatorta, J., Peres, K. W., Gray, S. M., van Eck, J., Yeam, I. and Jahn, M. 2011. Engineering virus resistance using a modified potato gene. Plant Biotechnol. J. 9:1014-1021.

Chavez, R., Brown, C. R. and Iwanaga, M. 1988. Transfer of resistance to PLRV titer buildup from Solanum etuberosum to cultivated potato germplasm. Theor. Appl. Genet. 76:129-135.

Chi, S. Q., Song, Y. Z., Zhu, C. X., Zheng, C. C., Liu, X. L. and Wen, F. J. 2005. Effect of matrix attachment regions on the RNA-mediated resistance induced by $\mathrm{PVY}^{\mathrm{N}}-\mathrm{CP}$ gene. Acta Phytopathol. Sinica 35:345-351.

Chung, B. N. and Palukaitis, P. 2011. Resistance to multiple viruses in transgenic tobacco expressing fused, tandem repeat, virus-derived double-stranded RNAs. Virus Genes 43:454464.

Cockerham, G. 1943. Potato breeding for virus resistance. Ann. Appl. Biol. 30:105-108.

Cockerham, G. 1955. Strains of potato virus X. In: Proceedings of the $2^{\text {nd }}$ Conference Potato Viruses Diseases, Lisse-Wageningen, 1954, ed. by E. Streutgers, A. B. R. Beemster and J. P. H. van der Want, pp. 89-92, H. Veenman \& Zonen, Wageningen, The Netherlands.

Cockerham, G. 1958. Experimental breeding in relation to virus resistance. In: Proceedings of the $3^{\text {rd }}$ Conference Potato Viruses Diseases, Lisse-Wageningen, 1957, ed. by F. Quak, J. Dijkstra, A. B. R. Beemster and J. P. H. van der Want, pp. 199-203, H. Veenman \& Zonen, Wageningen, The Netherlands.

Cockerham, G. 1970. Genetical studies on resistance to potato viruses X and Y. Heredity 25:309-348.

Dasgupta, I., Malathi, V. G. and Mukherjee, S. K. 2003. Genetic engineering for virus resistance. Curr. Sci. 84:341-354.

Davidson, T. M. W. 1973. Assessing resistance to leafroll in potato seedlings. Potato Res. 16:99-108.

Davidson, T. M. W. 1980. Breeding for resistance to virus disease of the potato (Solanum tuberosum) at the Scottish Plant Breeding Station. In: Scottish Plant Breeding Station $59^{\text {th }}$ Annu. Rep., pp. 100-108.

Doreste, V., Ramos, P. L., Enriquez, G. A., Rodriguez, R., Peral, R. and Pujol, M. 2002. Transgenic potato plants expressing the Potato virus $X$ (PVX) coat protein gene developed resistance to the viral infection. Phytoparasitica 30:177-185.

Dziewonska, M. A. and Ostrowska, K. 1978. Resistance to Potato virus $M$ in certain wild potato species. Potato Res. 21:129131.

Ehrenfeld, N., Romano, E., Serrano, C. and Arce-Johnson, P. 2004. Replicase mediated resistance against Potato leafroll virus in potato Desiree plants. Biol. Res. 37:71-82.

Fernandez-Northcote, E. N. 1990. Variability of PVX and PVY and its relationship to genetic resistance. In: Control of Virus and Virus-Like Diseases of Potato and Sweet Potato: Report of the $3^{\text {rd }}$ Planning Conference, 1989, pp. 131-139, International Potato Center, Lima, Peru.

Flis, B., Hennig, J., Strzelczyk-Zyta, D., Gebhardt, C. and Marczewski, W. 2005. The Ry-f $f_{\text {sto }}$ gene from Solanum stoloniferum for extreme resistant to Potato virus $Y$ maps to potato chromosome XII and is diagnosed by PCR marker GP122 $2_{718}$ in PVY resistant potato cultivars. Mol. Breed. 15:95-101.
Fribourg, C. E. and Nakashima, J. 1984. Characterization of a new potyvirus from potato. Phytopathology 74:1363-1369.

Franco-Lara, L. and Barker, H. 1999. Characterisation of resistance to potato leafroll virus accumulation in Solanum phureja. Euphytica 108:137-144.

Fuchs, M., McFerson, J. R., Tricoli, D. M., McMaster, J. R., Deng, R. Z., Boeshore, M. L., Reynolds, J. F., Russell, P. F., Quemada, H. D. and Gonsalves, D. 1997. Canteloupe line CZW-30 containing coat protein genes of cucumber mosaic virus, zucchini yellow mosaic virus, and watermelon mosaic virus-2 is resistant to these three viruses in the field. Mol. Breed. 3:279-290.

Fuchs, M., Tricoli, D. M., Carney, K. J., Schesser, M., McFerson, J. R. and Gonsalves, D. 1998. Comparative virus resistance and fruit yield of transgenic squash with single and multiple coat protein genes. Plant Dis. 82:1350-1356.

Gase, G., Möller, K. H. and Schenk, G. 1988. Die Bestimmung der relativen Viruskonzentration zur Einschätzung der quantitativen Resistenz von Kartoffelgenotypen gegen das Kartoffelblattroll-Virus. Arch. Phytopath. Pflanzenschutz. 24:163-165.

Germundson, A., Sandgren, M., Barker, H., Savenkov, E. I. and Valkonen, J. P. T. 2002. Initial infection of roots and leaves reveals different resistance phenotypes associated with coat protein gene-mediated resistance to Potato mop-top virus. J. Gen. Virol. 83:1201-1209.

Gibson, R. W. and Pickett, J. A. 1983. Wild potato repels aphids by release of aphid alarm pheromone Nature 302:608-609.

Graham, M. W., Craig, S. and Waterhouse, P. M. 1997. Expression patterns of vascular-specific promoters RolC and Sh in transgenic potatoes and their use in engineering PLRV-resistant plants. Plant Mol. Biol. 33:729-735.

Hämäläinen, J. H., Watanabe, K. N., Valkonen, J. P. T., Arihara, A., Plaisted, R. L., Pehu, E., Miller, L. and Slack, S. A. 1997. Mapping and marker-assisted selection for a gene for extreme resistance to potato virus Y. Theor. Appl. Genet. 94:192-197.

Hämäläinen, J. H., Sorri, V. A., Watanabe, K. N., Gebhardt, C. and Valkonen, J. P. T. 1998. Molecular examination of a chromosome region that controls resistance to potato $\mathrm{Y}$ and A potyviruses in potato. Theor. Appl. Genet. 96:1036-1043.

Hämäläinen, J. H., Kerarainen, T., Gebhardt C., Watanabe, K. N. and Valkonen, J. P. T. 2000. Recessive and dominant genes interfere with the vascular transport of Potato virus $A$ in diploid potatoes. Mol. Plant-Microbe Interact. 13:402-412.

Hefferon, K. L., Khalilian, H. and AbouHaidar, M. G. 1997. Expression of the $\mathrm{PVY}^{\mathrm{O}}$ coat protein $(\mathrm{CP})$ under the control of the PVX CP gene leader sequence: Protection under greenhouse and filed conditions against $\mathrm{PVY} \mathrm{Y}^{\mathrm{O}}$ and $\mathrm{PVY}^{\mathrm{N}}$ infection in three potato cultivars. Theor. Appl. Genet. 94:287-292.

Hoekema, A., Huisman, M. J., Molendijk, L., van den Elzen, P. J. M. and Cornelissen, B. J. C. 1989. The genetic engineering of two commercial potato cultivars for resistance to potato virus X. Nature Biotechnol. 7:273-278.

Hutton, E. M. 1951. Possible genotypes conditioning virus resistance in the potato and tomato. J. Aust. Inst. Agric. Sci. $17: 132-138$.

Jones, R. A. C. 1982. Breakdown of potato virus-X resistance 
gene-Nx - selection of a group 4 strain from strain group 3. Plant Pathol. 31:325-331.

Jones, R. A. C. 1985. Further studies on resistance-breaking strains of potato virus X. Plant Pathol. 34:182-189.

Jones, R. A. C. 1990. Strain group specific and virus specific hypersensitive reactions to infection with potyviruses in potato cultivars. Ann. Appl. Biol. 117:93-105.

Jones, D. A. and Jones, J. D. G. 1997. The role of leucine-rich repeat proteins in plant defenses. Adv. Bot. Res. 24:89-167.

Kalazich, J. C. and Plaisted, R. L. 1991. Association between trichome characters and agronomic traits in Solanum tuberosum (L.) x S. berthaultii (Hawkes) hybrids. Am. Potato J. 68:833847.

Kawchuk, L. M. and Prüfer, D. 1999. Molecular strategies for engineering resistance against potato viruses. Can. J. Plant Pathol. 21:231-247.

Kawchuk, L. M., Martin, R. R. and McPherson, L. 1990. Resistance in transgenic potato expressing the potato leafroll virus coat protein gene. Mol. Plant-Microbe Interact. 3:301-307.

Kawchuk, L. M., Lynch, D. R., Martin, R. R., Kozub, G. C. and Farries, B. 1997. Field resistance to the potato leafroll luteovirus in transgenic and somaclone potato plants reduces tuber disease symptoms. Can. J. Plant Pathol. 19:260-266.

Kelly, K. B., Whitworth, J. L. and Novy, R. G. 2009. Mapping of the potato leafroll virus resistance gene, $R l r_{e t b}$, from Solanum etuberosum identifies interchromosomal translocations among its E-genome chromosomes 4 and 9 relative to the A-genome of Solanum L. sect. Petota. Mol. Breeding 23:489-500.

Kojima, R. and Lapierre, H. 1988. Potato leafroll virus. In: European Handbook of Plant Diseases, ed. by I. M. Smith, V. Dunez, D. H. Philips, R. A. Leliot and S. A. Archer, pp. 2324. Blackwell Scientific Publications, Oxford.

Kurppa, A. 1990. Potato mop-top virus: purification, preparation of antisera and detection by means of ELISA. Ann. Agric. Fenniae. 29:9-17.

Lawson, C., Kaniewski, W., Haley, L., Rozman, R., Newell, C., Sanders, P. and Tumer, N. E. 1990. Engineering resistance to mixed virus-infection in a commercial potato cultivar - resistance to potato virus $\mathrm{X}$ and potato virus $\mathrm{Y}$ in transgenic Russet Burbank. Nature Biotechnol. 8:127-134.

Lomonossoff, G. P. 1995. Pathogen-dreived resistance to plant viruses. Annu. Rev. Phytopathol. 33:323-343.

Maki-Valkama, T., Valkonen, J. P. T., Lehtinen, A. and Pehu, E. 2001. Protection against Potato virus $Y$ (PVY) in the field in potatoes transformed with the PVY P1 gene. Am. J. Potato Res. 78:209-214.

Malnøe, P., Farinelli, L., Collet, G. F. and Reust, W. 1994. Smallscale field-tests with transgenic potato, cv. Bintje, to test resistance to primary and secondary infections with potato virus Y. Plant Mol. Biol. 25:963-975.

Marano, M. R., Malcuit, I., De Jong, W. and Baulcombe, D. C. 2002. High-resolution genetic map of $\mathrm{Nb}$, a gene that confers hypersensitivity to Potato virus $X$ in Solanum tuberosum. Theor. Appl. Genet. 105:192-200.

Marczewski, W., Flis, B., Syller, J., Schafer-Pregl, R. and Gebhardt C. 2001. A major quantitative trait locus for resistance to
Potato leafroll virus is located in a resistance hotspot on potato chromosome XI and is tightly linked to N-gene-like markers. Mol. Plant-Microbe Interact. 14:1420-1425.

Matousek, J., Schroder, A. R. W., Trnena, L., Reimers, M., Baumstark, T., Dedic, P., Vlasak, J., Becker, I., Kreuzaler, F., Fladung, M. and Riesner, D. 1994. Inhibition of viroid infection by antisense RNA expression in transgenic plants. Biol. Chem Hoppe-Seyler 375:765-777.

Melander, M. 2006. Potato transformed with a 57-kDa readthrough portion of the Tobacco rattle virus replicase gene displays reduced tuber symptoms when challenged by viruliferous nematodes. Euphytica 150:123-130.

Melander, M., Lee, M. and Sandgren, M. 2001. Reduction of potato mop-top virus accumulation and incidence in tubers of potato transformed with a modified triple gene block gene of PMTV. Mol. Breed. 8:197-206.

Mills, W. R. 1965. Inheritance of immunity to potato virus X. Am. Potato J. 42:294-295.

Missiou, A., Kalantidis, K., Boutla, A., Tzortzakaki, S., Tanler, M. and Tsagris, M. 2004. Generation of transgenic potato plants highly resistant to Potato virus $Y$ (PVY) through RNA silencing. Mol. Breed. 14:185-197.

Moury, B., Caromel, B., Johansen, E., Simon, V., Chauvin, L., Jacquot, L., Kerlan, C. and Lefebvre, V. 2011. The helper component proteinase cistron of potato virus $\mathrm{Y}$ induces hypersensitivity and resistance in potato genotypes carrying dominant resistance genes on chromosome IV. Mol. Plant-Microbe Interact. 24:787-797.

Mottaghinia, L., Razmjou, J., Nouri-Ganbalani, G. and RafleeDastjerdi, H. 2011. Antibiosis and antixenosis of six commonly produced potato cultivars to the green peach aphid, Myzus persicae Sulzer (Hemiptera: Aphididea). Neotropic. Entomol. 40:380-386.

Munoz, F. J., Plaisted, R. L. and Thurston, H. D. 1975. Resistance to potato virus $\mathrm{Y}$ in Solanum tuberosum ssp. andigena. Am. Potato J. 52:107-115.

Murray, S. L., Thompson, G., Visser, A. and Berger, D. K. 2002. Transgenic potatoes (cv. Late Harvest) show increased tolerance to potato leafroll virus in greenhouse and field trials. $S$. African J. Sci. 98:97-101.

Nie, X. Z., Singh, R. P., Seabrook, J. E. A., Zeng, C. J., Molen, T. A., Singh, M. and Douglass, K. 2008. Expression of Potato virus $A$ coat protein gene in a resistant potato cultivar disrupts the virus induced hypersensitive responses. Can. J. Plant Pathol. 30:318-328.

Nielsen, S. L. and Mølgaard, J. P. 1997. Incidence, appearance and development of potato mop-top furovirus-induced spraing in potato cultivars and the influence on yield, distribution in Denmark and detection of the virus in tubers by ELISA. Potato Res. 40:101-110.

Novy, R. G., Gillen, A. M. and Whitworth, J. L. 2007. Characterization of the expression and inheritance of Potato leafroll virus (PLRV) and Potato virus $Y$ (PVY) resistance in three generations of germplasm derived from Solanum etuberosum. Theor. Appl. Genet. 114:1161-1172.

Okamoto, D., Nielsen, S. V. S., Albrechtsen, M. and Borkhardt, B. 
1996. General resistance against potato virus $Y$ introduced into a commercial potato cultivar by genetic transformation with $\mathrm{PVY}^{\mathrm{N}}$ coat protein gene. Potato Res. 39:271-282.

Palucha, A., Zagorski, W., Chrzanowska, M. and Hulanicka, D. 1998. An antisense coat protein gene confers immunity to potato leafroll virus in a genetically engineered potato. Eur. $J$. Plant Pathol. 104:287-293.

Palukaitis, P. and Zaitlin, M. 1997. Replicase-mediated resistance to plant virus disease. Adv. Virus Res. 48:349-377.

Piron, F., Nicolaï, M., Minoïa, S., Piednoir, E., Moretti, A., Salgues, A., Zamir, D., Caranta, C. and Bendahmane, A. 2010. An induced mutation in tomato eIF4E leads to immunity to two potyviruses. PLoS ONE 5:e11313.

Pompon, J., Quiring, D., Giordanengo, P. and Pelletier, Y. 2010. Characterization of Solanum chomatophilum resistance to 2 aphid potato pests, Macrosiphum euphorbiae (Thomas) and Myzus persicae (Sulzer). Crop Prot. 29:891-897.

Potato Genome Sequencing Consortium. 2011. Genome sequence and analysis of the tuber crop potato. Nature 475:189-195.

Prins, M., Laimer, M., Noris, E., Schubert, J., Wassenegger, M. and Tepfer, M. 2008. Strategies for antiviral resistance in transgenic plants. Mol. Plant Pathol. 9:73-83.

Querci, M., Owens, R. A., Bartolini, I., Lazarte, V. and Salazar, L. F. 1997. Evidence for heterologous encapsidation of potato spindle tuber viroid in particles of potato leafroll virus. J. Gen. Virol. 78:1207-1211.

Racman, D. S., McGeachy, K., Reavy, B., Strukelj, B., Zel, J. and Barker, H. 2001. Strong resistance to potato tuber necrotic ringspot disease in potato induced by transformation with coat protein gene sequences from an NTN isolate of Potato virus Y. Ann. Appl. Biol. 139:269-275.

Rizvi, S. A. H. and Raman, K. V. 1983. Effect of glandular trichomes on the spread of potato virus Y (PVY) and potato leafroll virus (PLRV) in the field. In :Research for the potato in the year 2000. pp 162-163, Centro Internacional de la Papa. Lima. Peru.

Ross, H. 1954. Die Vererbung der 'Imunität' gegen das X-virus in tetraploidem Solanum acaule. In Proceedings of the $9^{\text {th }}$ International Congress of Genetics, Bellagio, 1953. Caryologia 6 (suppl.):1128-1132.

Ross, H. 1961. Über die Vererbung von Eigenschaften für Resistenz gegen das Y- und A-virus in Solanum stoloniferum und die mögliche Bedeutung für eine allgemeine Genetik der Virusresistenz in Slanum sect. Tuberarium. In: Proceedings of the $4^{\text {th }}$ Conference Potato Virus Diseases, Braunschweig, 1960, pp. 40-49, H. Veenman \& Zonen, Wageningen, The Netherlands.

Ross, H. 1966. The use of wild Solanum species in German potato breeding of the past and today. Am. Potato J. 43:64-80.

Ross, H. 1986. Potato breeding - problems and perspectives. In: Advances in Plant Breeding. J. Plant Breed. 13 (suppl.), ed. by J. Brandes, R. Bartels, J. Völk and C. Wetter, Paul Parey, Berlin.

Rovere, C. V., Asurmendi, S. and Hopp, H. E. 2001. Transgenic resistance in potato plants expressing the Potato leafroll virus (PLRV) replicase gene sequences is RNA-mediated and suggests the involvement of post-transcriptional gene silencing.
Arch. Virol. 146:1337-1353.

Salaman, R. N. 1921. Degeneration of potatoes. In: Report on the International Potato Conference, pp. 79-91. Royal Horticultural Society, London.

Salas, F. J. S., Lopes, J. R. S. and Fereres, A. 2010. Resistance of potato cultivars to Myzus persicae (Sulz.) (Hemiptera: Aphididae). Neotropic. Entomol. 39:1008-1015.

Sandgren, M. 1995. Potato mop-top virus (PMTV): distribution in Sweden, development of symptoms during storage and cultivar trials in field and glasshouse. Potato Res. 38:379-389.

Schouten, H. J., Krens, F. A. and Jacobsen, E. 2006. Cisgenic plants are similar to traditionally bred plants. EMBO Rep. 7:750-753.

Schubert, J., Matousek, J. and Mettern, D. 2004. Pathogenderived resistance in potato to Potato virus $Y$ - aspects of stability and biosafety under filed conditions. Virus Res. 100:4150.

Smith, H. A., Powers, H., Swaney, S., Brown, C. and Dougherty, W. G. 1995. Transgenic potato virus Y resistance in potato evidence for an RNA-mediated cellular-response. Phytopathology 85:864-870.

Sokolova, M. A., Pugin, M. M., Shulga, O. A. and Skryabin, K. G. 1994. Construction of transgenic potato plants resistant to potato-virus-Y. Mol. Biol. 28:646-649.

Solomon, R. M. and Wastie, R. L. 1988. Management of potato mop-top virus and its vector by breeding and selection. In: Developments in Applied Biology II. Viruses with Fungal Vectors, ed. by J. I. Cooper and M. J. C. Asher, pp 271-279, Assoc. Appl. Biologists, Wellesbourne, UK.

Solomon-Blackburn, R. M. and Barker, H. 2001a. Breeding virusresistant potatoes (Solanum tuberosum): a review of traditional and molecular approaches. Heredity 86:17-35.

Solomon-Blackburn, R. M. and Barker, H. 2001b. A review of host major-gene resistance to potato viruses $\mathrm{X}, \mathrm{Y}, \mathrm{A}$ and $\mathrm{V}$ in potato: genes, genetics and mapped locations. Heredity $86: 8-$ 16.

Solomon-Blackburn, R. M., Barker, H., Bradshaw, J. E. and De Jong, W. 2003/4. Evidence that resistance to potato leafroll virus accumulation in tetraploid Solanum tuberosum L. is controlled by one or few major genes that are not complementary. Potato Res. 46:137-145.

Song, Y. S., Hepting, L., Schweizer, G., Hartl, L., Wenzel, G. and Schwarzfischer, A. 2005. Mapping of extreme resistance to PVY $\left(R y_{\text {sto }}\right)$ on chromosome XII using anther-culture-derived primary dihaploid potato lines. Theor. Appl. Genet. 111:879887.

Spillane, C., Baulcombe, D. C. and Kavanagh, T. A. 1998. Genetic engineering of the potato cultivar Glenroe for increased resistance to potato virus X (PVX). Irish J. Agric. Food Res. 37:173-182.

Swiezynski, K. M. 1994. Inheritance of resistance to viruses. In: Potato Genetics, ed. by J. E. Bradshaw and G. R. Mackay, pp. 339-364, CAB International, Wallingford, UK.

Swiezynski, K. M., Dziewonska, M. A. and Ostrowska K. 1988. Reaction to the potato leafroll virus (PLRV) in diploid potatoes. Potato Res. 31:289-296. 
Swiezynski, K. M., Chrzanowska, M., Dziewonska, M. A. and Was, M. 1993. Durability of resistance to viruses in the potato. In: Durability of Disease Resistance, ed. by T. Jacobs and J. E. Parlevliet, p. 350, Klewer, Dordrecht, The Netherlands.

Szajko, K., Chrzanowska, M., Witek, K., Strzelczyk-Zyta, D., Zagorska, H., Gebhardt, C., Hennig, J. and Marczewski, W. 2008. The novel gene $\mathrm{Ny}-1$ on potato chromosome IX confers hypersensitive resistance to Potato virus $Y$ and is an alternative to $R y$ genes in potato breeding for PVY resistance. Theor. Appl. Genet. 116:297-303.

Thomas, P. E., Lawson, E. C., Zalewski, J. C., Reed, G. L. and Kaniewski, W. K. 2000. Extreme resistance to Potato leafroll virus in potato cv. Russet Burbank mediated by the viral replicase gene. Virus Res. 71:49-62.

Tingey, W. M. and Laubengayer, J. E. 1981. Defense against the green peach aphid (Homoptera, Aphididae) and potato leafhopper (Homoptera, Cicadellidae) by glandular trichomes of Solanum-berthaultii. J. Econ. Entomol. 74:721-725.

Tomato Genome Consortium. 2012. The tomato genome sequence provides insights into fleshy fruit evolution. Nature 485:635641.

Tommiska, T. J., Hämäläinen, J. H., Watanabe, K. N. and Valkonen, J. P. T. 1998. Mapping of the gene $N x_{p h u}$ that controls hypersensitive resistance to potato virus X in Solanum pheruja IvP35. Theor. Appl. Genet. 96:840-843.

Valkonen, J. P. T., Slack, S. A., Plaisted, R. L. and Watanabe, K. N. 1994. Extreme resistance is epistatic to hypersensitive resistance to potato virus $\mathrm{Y}^{\circ}$ in Solanum tuberosum subsp. Andigena-derived potato genotype. Plant Dis. 78:1177-1180.

Valkonen, J. P. T., Puurand, U., Slack, S. A., Mäkinen, K. and Saarma, M. 1995a. Three strain groups of potato A potyvirus based on hypersensitive responses in potato, serological properties, and coat protein sequences. Plant Dis. 79:748-753.

Valkonen, J. P. T., Orillo, M., Slack, S. A., Plaisted, R. L. and Watanabe, K. N. 1995b. Resistance to viruses in F1 hybrids produced by direct crossing between diploid Solanum series Tuberosa and diploid S. brevidens (series Etuberosa) using $S$. pheruja for rescue pollination. Plant Breed. 114:421-426.

Valkonen, J. P. T., Wiegmann, K., Hämäläinen, J. H., Marczewski, W. and Watanabe, K. N. 2008. Evidence for utility of the same PCR-based markers for selection of extreme resistance to Potato virus $Y$ controlled by $R y_{\text {sto }}$ of Solanum stoloniferum derived from different sources. Ann. Appl. Biol. 152:121-130.

Van den Heuvel, J. F. J. M., Dirven, J. A. A. M., Van Os, G. J. and Peters, D. 1993. Acquisition of potato leafroll virus by Myzus persicae from secondarily-infected potato plants of different genotypes. Potato Res. 36:89-96.

Was, M. and Dziewonska, M. A. 1984. Reaction of PVM and PVS in potato clones with the genes Gm and Ns. In: 9th Triennial Conference of the European Association of Potato Researchers, Interlaken, ed. by F. A. Winiger and A. Stockli, pp. 245-246, European Association of Potato Research.

Wefels, E., Salamini, F. and Rohde, W. 1993. Modification at the $\mathrm{N}$-terminus of the potato virus Y capsid protein (CP) does not interfere with the CP-mediated virus resistance in transgenic potato (Solanum tuberosum L.). J. Genet. Breed. 47:89-93.

Wilson, C. R. and Jones, R. A. C. 1993. Evaluation of resistance to potato leafroll virus in selected potato cultivars under field conditions. Aust. J. Exp. Agric. 33:83-90.

Xu, H., Khalian, H., Eweida, M., Squire, S. and Abouhaidar, M. G. 1995. Genetically-engineered resistance to potato-virus X in 4 commercial potato cultivars. Plant Cell Rep. 15:91-96.

Yang, X., Yie, Y., Zhu, F., Liu, Y., Kang, L., Wang, X. and Tien, P. 1997. Ribozyme-mediated high resistance against potato spindle tuber viroid in transgenic potatoes. Proc. Natl. Acad. Sci. USA 94:4861-4865.

Zhu, C. X., Song, Y. Z. and Wen, F. J. 2008. Constructing transgenic tobacco for multiple-resistance against Potato virus Y, Cucumber mosaic virus and Tobacco mosaic virus. Scien. Agric. Sinica 41:1040-1047. 